\title{
PREFERENSI MASYARAKAT DALAM MEMILIH APARTEMEN DENGAN MENGGUNAKAN METODE FUZZY ANALYTICAL HIERARCHY PROCESS (F-AHP) DI KOTA DEPOK
}

\author{
${ }^{1)}$ Mega Hafizha, ${ }^{2)}$ Setiono, ${ }^{3)}$ Suryoto \\ 1) Mahasiswa Program Studi Teknik Sipil Fakultas Teknik Universitas Sebelas Maret \\ 2),3) Pengajar Program Studi Teknik Sipil Fakultas Teknik Universitas Sebelas Maret \\ Jl. Ir. Sutami 36 A, Kentingan Surakarta 57126 \\ Email :megahaviza97@gmail.com
}

\begin{abstract}
Depok city directly adjacent to the Special Capital Region of Jakarta, is one of the buffer areas to relieve the pressure of the development of DKI Jakarta as the capital city of Indonesia, which is directed towards more equitable settlement patterns and equal distribution of job opportunities. Moreover, Depok city is known as an educational center, this is seen from the number of educational institutions spread across Depok city, especially in Margonda area. With these conditions, the number of people who come and live in Depok city will continue to increase from year to year, this is directly proportional to the increasing demand for housing needs, including the demand for apartments as a place to live. Based on the results of previous studies indicate that there are factors that influence people's preferences in choosing an apartment. Therefore, this writing aims to determine people's preferences in choosing an apartment and find out the most factor and the least factor affects people's preferences in choosing an apartment in Depok. City. The methods used in this study are qualitative descriptive and weighting methods with the Furay Analytical Hierarchy Process (FAHP) method. Data collection is done through the survey method in the form of questionnaires and the results of the decisions from the questionnaire were processed using the Microsoft Excel 2016 Software Program. As the result, there were 5 main factors that influence the community in choosing an apartment in Depok City, including: products, price perception, location, apartment facilities, and legality. After being processed by the F-AHP method, from 10 respondents who were the subject of the study, obtained the most affecting factor in the community was the location of the apartment which was close to social facilities and the least affecting factor in the community is the Developer who developed the apartment.
\end{abstract}

Keywords: Choosing apartment, Fuzzy Analytical Hierarchy Process Method (F-AHP), populations preferences

\begin{abstract}
Abstrak
Kota Depok merupakan salah satu daerah penyangga Ibu Kota Jakarta, dimana keberadaannya diarahkan sesbagai pola pemukiman dan penyebaran kesempatan kerja secara lebih merata, sebagai upaya meringankan tekanan perkembangan penduduk DKI Jakarta. Banyaknya lembaga, institusi serta perguruan tinggi yang tersebar di Kota Depok, terutama di Jalan Margonda Raya, menjadikan Kota Depok dikenal sebagai sentra pendidikan. Hal ini berimbas kepada jumlah penduduk yang datang dan menetap di Kota Depok, dimana akan terus mengalami peningkatan setiap tahunnya. Kondisi ini tentunya berbanding lurus terhadap meningkatnya permintaan kebutuhan akan tempat tinggal, tak terkecuali permintaan terhadap apartemen sebagai tempat tinggal. Berdasarkan hasil kajian serta penelitian sebelumnya, selera masyarakat dalam memilih apartemen dipengaruhi oleh beberapa faktor. Oleh karena itu, penulisan ini bertujuan untuk mengetahui faktor apa saja yang dapat mempengaruhi preferensi masyarakat dalam memilih apartemen khususnya di Kota Depok. Metode yang digunakan dalam penelitian kali ini yaitu deskriptif kualitatif serta pembobotan dengan metode Fuz:y Analytical Hierarchy Process (F-AHP). Pengumpulan data dilakukan melalui metode survei berupa kuesioner dan hasil keputusan dari kuesioner diolah menggunakan Program Software Microsoft Excel 2016. Sebagai hasil, dalam memilih apartemen di Kota Depok, masyarakat akan mempertimbangakan beberapa fakor antara lain: produk, persepsi harga, lokasi, fasilitas apartemen, dan legalitas. Kemudian, dari 10 responden yang menjadi subjek penelitian, diperoleh faktor yang paling mempengaruhi masyarakat yaitu dekat dengan fasilitas sosial dan yang paling tidak mempengaruhi masyarakat adalah nama besar pengembang (Developer). Hasil tersebut didapatkan salah satunya karena lokasi apartemen yang ditinjau berada di jalan utama Kota Depok yaitu Jalan Margonda Raya, dimana terdapat banyak fasilitas sosial seperti sarana Pendidikan, Kesehatan, Olahraga, Rekreasi, maupun Pusat Perbelanjaan
\end{abstract}

Kata Kunci : Fuz:y Analytical Hierarchy Process (F-AHP), pemilihan apartemen, preferensi masyarakat

\section{PENDAHULUAN}

Tempat tinggal memiliki berbagai fungsi, baik sebagai tempat berlindung maupun tempat berkumpul dan bercengkrama bersama keluarga dan orang-orang terdekat. Jenis tempat tinggal yang umumnya dihuni oleh masyarakat yaitu rumah, perumahan, rumah susun, kondominium dan juga apartemen. Semakin meningkatnya jumlah penduduk dari tahun ke tahun, permintaan akan apartemen sebagai tempat tinggal juga pasti akan turut meningkat.

Kota Depok terletak pada koordinat 6 $6^{\circ} 19^{\prime} 00^{\prime \prime}-6^{\circ} 28^{\prime} 00^{\prime \prime}$ Lintang Selatan dan $106^{\circ} 43^{\prime} 00^{\prime \prime}-106^{\circ} 55^{\prime} 30^{\prime \prime}$ Bujur Timur. Berdasarkan Rencana Pembangunan Jangka Menengah Daerah (RPJMD) Kota Depok Tahun 2006 - 2011, "kota Depok mempunyai keunggulan komparatif yang cukup besar, terutama letaknya yang sangat strategis ditinjau dari segi politik, ekonomi, sosial, budaya dan pertahanan keamanan. Wilayah ini berbatasan langsung dengan 
wilayah Daerah Khusus Ibukota Jakarta, dan merupakan wilayah yang diarahkan untuk pola pemukiman dan penyebaran kesempatan kerja secara lebih merata. Dalam perkembangannya selanjutnya, Kota Depok telah tumbuh sebagai kota perdagangan dan jasa yang mandiri. Kota Depok semakin tumbuh dengan pesat seiring dengan meningkatnya perkembangan jaringan transportasi yang tersinkronisasi secara regional dengan kota-kota lainnya, hal ini dikarenakan lokasi Kota Depok yang berada diantara Kota Jakarta dan Kota Bogor yang menjadikan letak Kota Depok yang sangat strategis. (Bappeda Kota Depok, 2017)

Tolok ukur keberhasilan bisnis apartemen adalah banyaknya unit yang terjual kepada konsumen. Oleh karena itu pengembang perlu mengetahui perilaku konsumen dalam memilih apartemen yang sesuai kebutuhan. Terdapat berbagai alternatif seperti lokasi, harga, cara pembayaran maupun desain yang dapat ditawarkan oleh pengembang kepada konsumen. Dalam memilih apartemen, konsumen harus pandai mempertimbangkan alternatif apartemen yang sesuai dengan keinginan dan kebutuhannya. Untuk mengetahui preferensi masyarakat dalam memilih apartemen di Kota Depok, salah satu metode pengambilan keputusan yang dapat digunakan yaitu metode AHP (Analytical Hierarchy Process) dengan pendekatan Fur:zy.

\section{METODE}

Metode pada penelitian ini adalah metode deskriptif kualitatif, yaitu dengan mengidentifikasi faktor-faktor yang berpengaruh dalam pemilihan apartemen. Terdapat dua jenis data yang digunakan, yaitu data primer dan data sekunder. Data primer didapatkan dari hasil penggalian pendapat menggunakan kuesioner berbentuk rating scale. Dimana, responden diminta mengisi kolom yang telah disediakan dari tingkat sangat penting sampai tidak penting sesuai dengan petunjuk yang tertera pada kuesioner. Responden dari penelitian yaitu penghuni, penyewa maupun pembeli apartemen yang menjadi tinjauan di Kota Depok. Sedangkan data sekunder merupakan data-data yang relevan dengan tujuan penelitian yang bersumber dari buku, internet, jurnal dan penelitian terdahulu. Analisis data yang digunakan bersifat deskriptif, menggunakan metode Fuz:y Analytical Hierarchy Process (F-AHP) dengan bantuan Software Microsoft Excel 2016 sebagai metode pembobotan yang digunakan. Penelitian dilakukan dalam kurun waktu antara Bulan Juli sampai bulan September 2020.

\section{Fuzzy Analitycal Hierarchy Process (F-AHP)}

Penggabungan dari metode Analytical Hierarchy Process dengan pendekatan konsep Fuz:y menghasilkan suatu metode yaaitu Fuz:y Analytical Hierarcby Process (Rahardjo, dkk, 2002). Keunggulan dari metode F-AHP yaitu untuk mengatasi kekurangan pada metode AHP, dimana pada metode AHP kriteria yang digunakan cenderung bersifat subyektif karena bersumber dari pendapat para ahli. Selain itu, F-AHP digunakan dalam mengatasi ketidakpastian bilangan yang dipresentasikan dengan urutan skala (Jasril, dkk, 2011). Untuk mengatasi ketidakpastian bilangan inilah, perlu dilakukan tahapan fuzzifikasi dengan menentukan derajat keanggotaan pada F-AHP. Fuzzifikasi dilakukan dengan mengubah suatu bilangan ke dalam bentuk bilangan fuzzy dengan menggunakan Triangular Fur:y Number (TFN).

Triangular Fu₹氵y Number (TFN) adalah suatu himpunan fuz:y yang digunakan untuk mengubah suatu penilaian subjektif manusia dalam bahasa atau linguistik yang bersifat crisp (bukan fuz:y).

Pengukuran yang berhubungan dengan penilaian subjektif manusia memakai bahasa atau linguistik. Input utama dari tahapan fuzzzifikasi ini terletak pada perbandingan berpasangan yang digambarkan dengan skala rasio 1-9 yang berhubungan dengan skala fur:y. Berikut grafik fungsi keanggotaan segitiga.

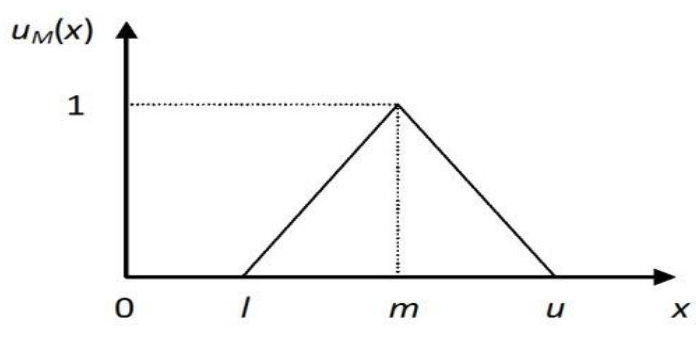

Gambar 1. Fungsi keanggotaan segitiga Sumber: Chang, 1996

TFN dikelompokkan kedalam 3 nilai, yaitu $l, m$, dan $u$, dimana $l$ adalah nilai terendah, $m$ adalah nilai tengah, $u$ adalah nilai teratas $(1 \leq \mathrm{m} \leq \mathrm{u})$. 


\section{HASIL DAN PEMBAHASAN}

\section{Faktor-Faktor yang Mempengaruhi Pemilihan Apartemen}

Setelah dilakukan kajian jurnal, buku serta penelitian terdahulu tentang faktor pemilihan apartemen, peneliti melakukan analisis tentang faktor yang menjadi penentu pemilihan apartemen yang terdapat pada Tabel 1.

Tabel 1. Analisis faktor penentuan lokasi

\begin{tabular}{|c|c|c|}
\hline Faktor & Subfaktor & Sumber \\
\hline Produk & $\begin{array}{l}\text { - Potensi untuk disewakan (Yield) dan Kenaikan Harga (Capital Gain) } \\
\text { - Nama Besar Pengembang (Developer) } \\
\text { - Reputasi Kontraktor yang membangun } \\
\text { - Desain Apartemen }\end{array}$ & $\begin{array}{l}\text { 1. Rabinowitz dalam Catanese (1989) } \\
\text { 2. Yance Onggo, dkk (2018) }\end{array}$ \\
\hline $\begin{array}{l}\text { Persepsi } \\
\text { Harga }\end{array}$ & $\begin{array}{ll}\text { - } & \text { Harga } \\
\text { - } & \text { Besar DP/uang muka minimum KPA } \\
\text { - } & \text { Kemudahan pembayaran bertahap (angsuran) }\end{array}$ & $\begin{array}{l}\text { 1. Goodall (1972) } \\
\text { 2. Yance Onggo, dkk (2018) }\end{array}$ \\
\hline Lokasi & $\begin{array}{ll}\text { - } & \text { Terjangkau oleh Transportasi Umum } \\
\text { - } & \text { Dekat dengan Pusat CBD (Central Business District) } \\
\text { - } & \text { Dekat dengan Fasilitas Sosial (Kesehatan, Pendidikan, Olahraga, } \\
& \text { Rekreasi dan Pusat Perbelanjaan) }\end{array}$ & $\begin{array}{l}\text { 1. Turner (1976) } \\
\text { 2. Hodgkinson \& Allen (1982) } \\
\text { 3. Peraturan Pemerintah Republik } \\
\text { Indonesia No.4 (1988) }\end{array}$ \\
\hline $\begin{array}{l}\text { Fasilitas } \\
\text { Apartemen }\end{array}$ & $\begin{array}{l}\text { - Fasilitas Penunjang (Kolam Renang/Fitness Center/Jogging } \\
\text { Track/Taman Bermain Anak/Ruang Serba Guna) } \\
\text { - Sarana Utilitas (air bersih, jaringan telepon, listrik, gas, drainase, dan } \\
\text { tanda bahaya/alarm) } \\
\text { - Access Card khusus Penghuni } \\
\text { - Ketersediaan lahan Parkir }\end{array}$ & $\begin{array}{l}\text { 1. Joseph de Chiara dalam Prasetya } \\
\text { (2015) } \\
\text { 2. Rabinowitz dalam Catanese (1989) } \\
\text { 3. Yance Onggo, dkk (2018) }\end{array}$ \\
\hline Legalitas & $\begin{array}{ll}\text { - } & \text { Status Sertifikat Lahan (HGB Murni/HPL) } \\
\text { - } & \text { Sertifikat Kepemilikan Unit }\end{array}$ & $\begin{array}{l}\text { 1. Joseph de Chiara dalam Prasetya } \\
\text { (2015) } \\
\text { 2. Rabinowitz dalam Catanese (1989) } \\
\text { 3. Yance Onggo, dkk (2018) }\end{array}$ \\
\hline
\end{tabular}

\section{Analisis Bobot Faktor Utama}

Analisis bobot dilakukan menggunakan metode Fursy Analytical Hierarchy Process (F-AHP) dengan bantuan Software Microsoft Excel 2016. Terdapat lima faktor utama yang menjadi kriteria penilaian, setelah dilakukan analisis, didapatkan bobot nilai terbesar untuk factor utama pada faktor fasilitas apartemen sebesar 27,88\%. Kemudian faktor dengan nilai bobot terkecil adalah faktor produk sebesar $14,84 \%$.

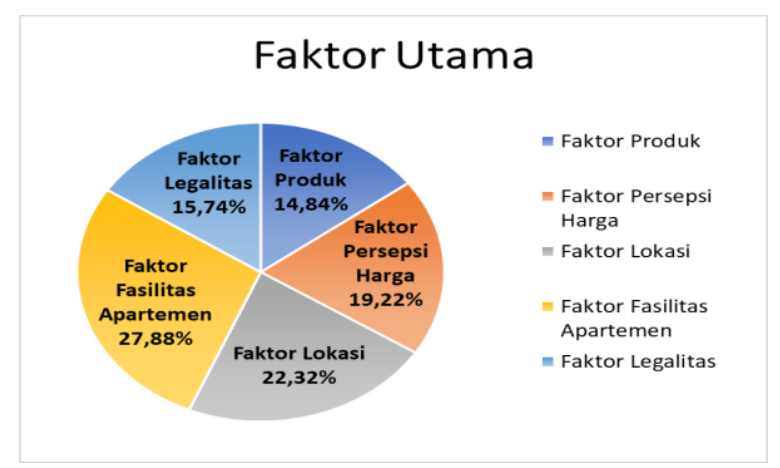

Gambar 2. Bobot nilai faktor utama

Sumber: Hasil Penelitian

\section{Analisis Bobot Subfaktor Produk}


Terdapat empat subfaktor pada faktor produk yang menjadi kriteria penilaian, setelah dilakukan analisis, didapatkan bobot nilai terbesar pada subfaktor desain apartemen sebesar 61,08\%. Kemudian subfaktor dengan nilai bobot terkecil adalah subfaktor nama besar developer sebesar 7,98\%.

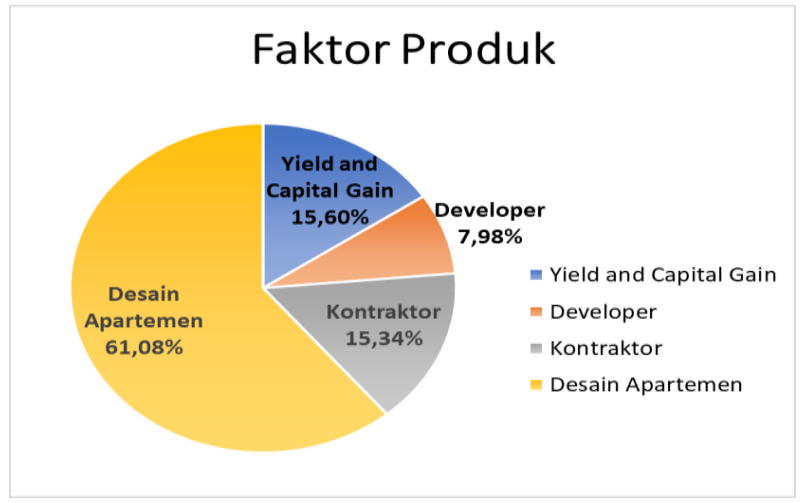

Gambar 3. Bobot nilai faktor produk Sumber: Hasil Penelitian

\section{Analisis Bobot Subfaktor Persepsi Harga}

Terdapat tiga subfaktor pada faktor persepsi harga yang menjadi kriteria penilaian, setelah dilakukan analisis, didapatkan bobot nilai terbesar pada subfaktor angsuran sebesar 34,03\%. Kemudian subfaktor dengan nilai bobot terkecil adalah subfaktor harga sebesar $32,12 \%$.

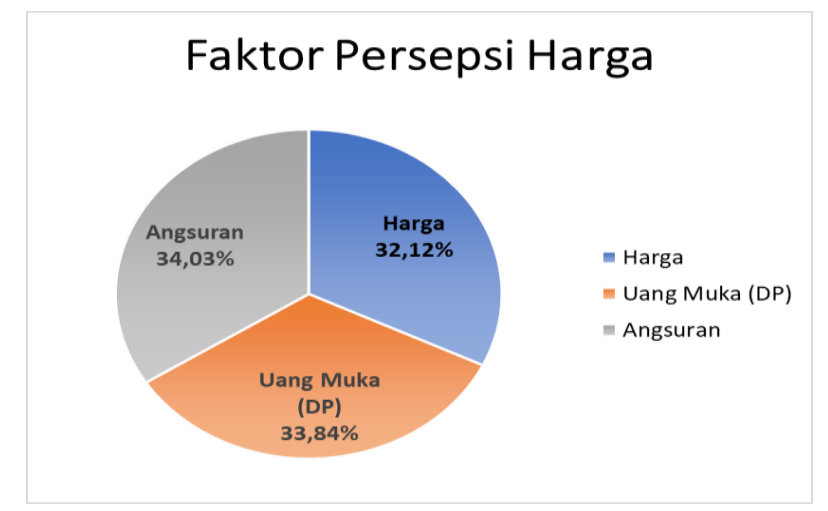

Gambar 4. Bobot nilai faktor persepsi harga

Sumber: Hasil Penelitian

\section{Analisis Bobot Subfaktor Lokasi}

Terdapat tiga subfaktor pada faktor lokasi yang menjadi kriteria penilaian, setelah dilakukan analisis, didapatkan bobot nilai terbesar pada subfaktor dekat dengan fasilitas sosial sebesar 43,30\%. Kemudian subfaktor dengan nilai bobot terkecil adalah subfaktor dekat dengan pusat CBD sebesar 18,47\%.

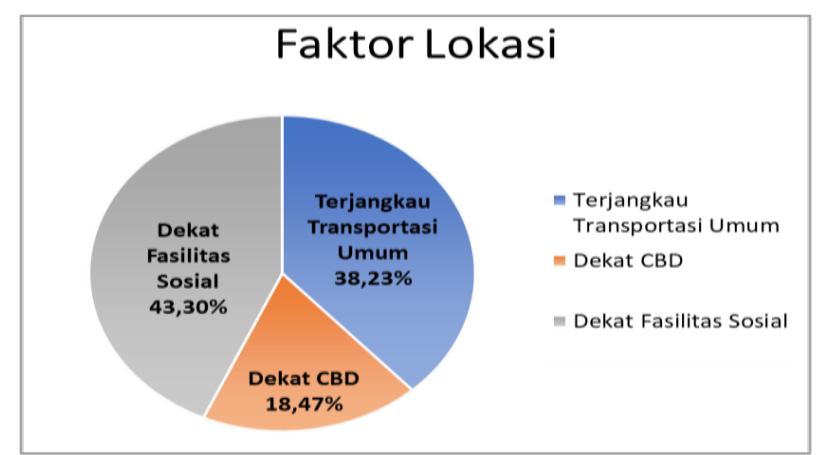

Gambar 5. Bobot nilai faktor lokasi

Sumber: Hasil Penelitian 


\section{Analisis Bobot Subfaktor Fasilitas Apartemen}

Terdapat empat subfaktor pada faktor fasilitas apartemen yang menjadi kriteria penilaian, setelah dilakukan analisis, didapatkan bobot nilai terbesar pada subfaktor access card sebesar 32,61\%. Kemudian subfaktor dengan nilai bobot terkecil adalah subfaktor fasilitas penunjang sebesar 15,66\%.

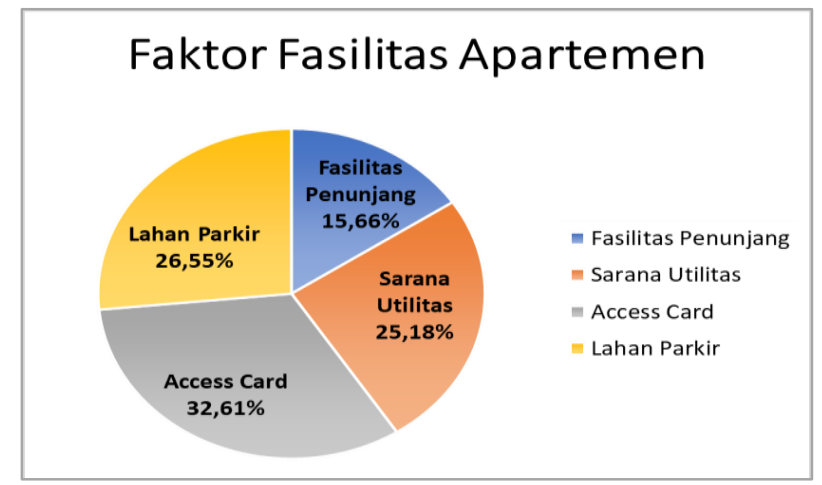

Gambar 6. Bobot nilai faktor fasilitas apartemen Sumber: Hasil Penelitian

\section{Analisis Bobot Subfaktor Legalitas}

Terdapat dua subfaktor pada faktor legalitas yang menjadi kriteria penilaian, setelah dilakukan analisis, didapatkan bobot nilai terbesar pada subfaktor sertifikat kepemilikan unit sebesar 55,00\%. Kemudian subfaktor dengan nilai bobot terkecil adalah subfaktor status sertifikat lahan sebesar 45,00\%.

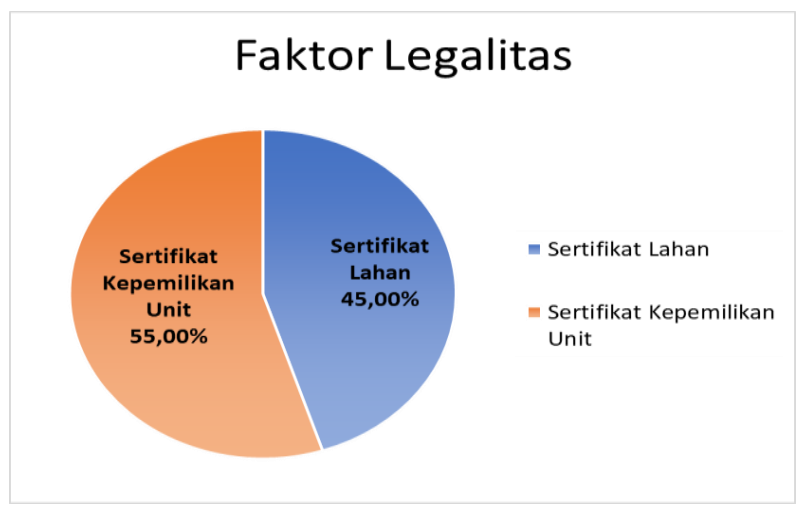

Gambar 7. Bobot nilai faktor legalitas Sumber: Hasil Penelitian

\section{Analisis Subfaktor Keseluruhan}

Secara keseluruhan, terdapat 16 subfator yang digunakan dalam penelitian ini, setelah dianalisi, subfaktor dekat dengan fasilitas sosial memiliki nilai terbesar, yaitu 9,67\%. Sedangkan, subfaktor nama besar developer memiliki nilai terkecil, yaitu 1,18\%. Berikut merupakan bobot per kriteria sesuai dengan urutan terbesar sampai dengan terkecil, sebagai berikut:

Tabel 2. Bobot nilai subfaktor keseluruhan

\begin{tabular}{lll}
\hline No & \multicolumn{1}{c}{ Kriteria Pembobotan } & Bobot Per Item \\
\hline 1. & Dekat Fasilitas Sosial & $9,67 \%$ \\
2. & Access Card & $9,09 \%$ \\
3. & Desain Apartemen & $9,07 \%$ \\
4. & Sertifikat Kepemilikan Unit & $8,66 \%$ \\
$\mathbf{5 .}$ & Terjangkau Transportasi Umum & $8,53 \%$ \\
$\mathbf{6 .}$ & Ketersediaan Lahan Parkir & $7,40 \%$ \\
7. & Status Sertifikat Lahan & $7,08 \%$ \\
$\mathbf{8 .}$ & Sarana Utilitas & $7,02 \%$ \\
9. & Angsuran & $6,54 \%$ \\
10. & Uang Muka (DP) & $6,50 \%$ \\
11. & Harga & $6,17 \%$
\end{tabular}


Jurnal Matriks Teknik Sipil

DOI: https://doi.org/10.20961/mateksi.v8i3

ISSN: $2354-8630$

E-ISSN: 2723-4223

Vol 8, No 4 (2020): Desember

\begin{tabular}{llll}
\hline No & & Kriteria Pembobotan & Bobot Per Item \\
\hline 12. & Fasilitas Penunjang & & $4,36 \%$ \\
13. & Dekat Pusat CBD & $4,12 \%$ & \\
14. & Yield dan Capital Gain & $2,32 \%$ & \\
15. & Kontraktor & $2,28 \%$ & \\
16. & Developer & $1,18 \%$ & \\
\hline
\end{tabular}

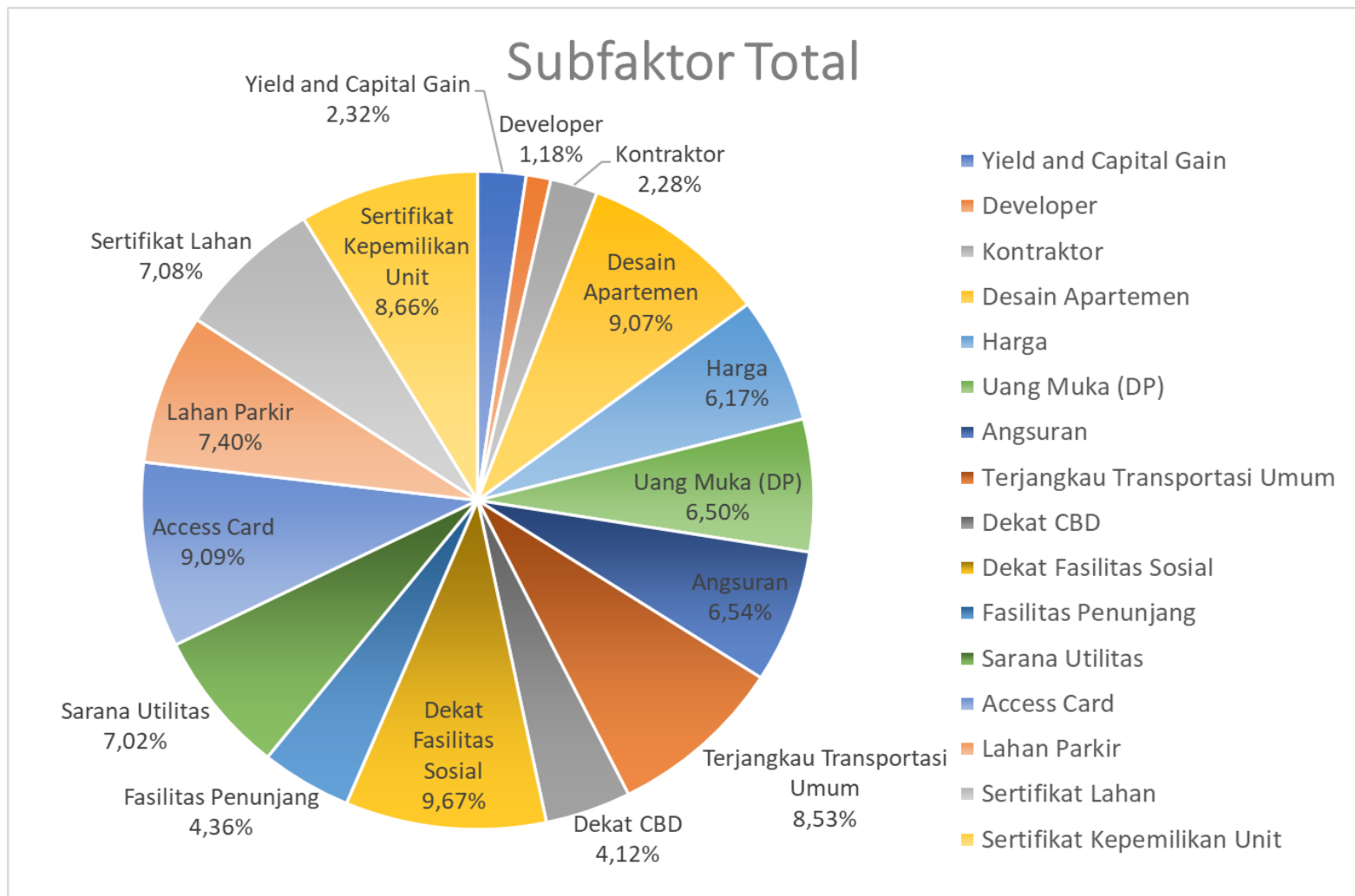

Gambar 8. Bobot nilai subfaktor keseluruhan

Sumber: Hasil Penelitian

\section{KESIMPULAN}

Berdasarkan hasil penelitian serta analisis data dan pembahasan yang telah dilakukan terhadap keputusan masyarakat dalam memilih apartemen di Kota Depok, didapatkan hasil berdasarkan urutan faktor yang paling mempengaruhi sampai dengan yang paling tidak mempengaruhi, sebagai berikut:

1. Dekat Fasilitas Sosial $(9,67 \%)$

2. Access Card $(9,09 \%)$

3. Desain Apartemen (9,07\%)

4. Sertifikat Kepemilikan Unit (8,66\%)

5. Terjangkau Transportasi Umum $(8,53 \%)$

6. Ketersediaan Lahan Parkir $(7,40 \%)$

7. Status Sertifikat Lahan $(7,08 \%)$

8. Sarana Utilitas $(7,02 \%)$

9. Kemudahan Pembayaran Angsuran (6,54\%)

10. Besar Uang Muka (6,50\%)

11. Harga $(6,17 \%)$

12. Fasilitas Penunjang $(4,36 \%)$

13. Dekat dengan Pusat CBD $(4,12 \%)$

14. Yield dan Capital Gain $(2,32 \%)$

15. Reputasi Kontraktor $(2,28 \%)$

16. Nama Besar Developer $(1,18 \%)$

Dapat disimpulkan bahwa yang paling mempengarungi keputusan masyarakat dalam memilih apartemen di Kota Depok adalah subfaktor Dekat dengan Fasilitas Sosial. Hasil tersebut didapatkan salah satunya karena lokasi 
apartemen yang ditinjau berada di jalan utama Kota Depok yaitu Jalan Margonda Raya, dimana terdapat banyak fasilitas sosial seperti sarana Pendidikan, Kesehatan, Olahraga, Rekreasi, maupun Pusat Perbelanjaan.

\section{UCAPAN TERIMAKASIH}

Atas berkat rahmat Allah SWT, peneliti mengucapkan terimakasih kepada kedua orang tua dan keluarga yang telah memberikan dukungan baik materil serta non-material, juga kepada Almamater Universitas Sebelas Maret Surakarta khususnya Program Studi Teknik Sipil Fakultas Teknik. Tidak lupa peneliti juga mengucapkan terimakasih kepada seluruh pihak yang ikut turut membantu dalam penyusunan laporan skripsi ini hingga dapat terselesaikan dengan baik.

\section{REFERENSI}

Bappeda Kota Depok, 2017, “Kota Depok”, https://bappeda.depok.go.id/profil.html. Diakses pada 21 September 2020 pukul 10.30 WIB.

Chang, D.Y., 1996, “Application of The Extent Analysis Method on Fuzzy AHP”, European Journal of Operational Research. Vol. 95, pp. 649-655.

De Chiara, Joseph., 1973, “Times-Saver Standards for Building Types”, Mcgraw-Hill (Tx). Texas.

De Chiara, Joseph., 1984, “Times-Saver Standards for Residential Development”, Mcgraw-Hill (Tx). Texas

Goodall., 1972, “Grub: The Bush Baby Boston: Houghton Mifflin”, Houghton Mifflin. Boston.

Jasril, Haerani, E., dan Afrianty, I., 2011, "Sistem Pendukung Keputusan (SPK) Pemilihan Karyawan Terbaik Menggunakan Metode Fuzzy AHP (F-AHP)”, Seminar Nasional Aplikasi Teknologi Informasi 2011, Yogyakarta.

Onggo, Yance dkk, 2018, "Faktor yang Menentukan Keputusan Membeli Apartemen”, Jurnal. Program MM Sekolah Bisnis dan Ekonomi Universitas Prasetya Mulya.

Pemerintah Daerah Kota Depok, 2006, "Peraturan Daerah Kota Depok Nomor 02 Tahun 2006 tentang Rencana Pembangunan Jangka Menengah Daerah (RPJMD) Kota Depok Tahun 2006-2011"

Pemerintah Republik Indonesia, 1998, "Peraturan Pemerintah Republik Indonesia Nomor 4 Tahun 1998 tentang Rumah Susun".

Rabinowitz, H.Z., 1988, "Real Estate Planning”, McGraw Hill Inc. New York.

Rahardjo, A., dan Sutapa, I. N., 2002, “Aplikasi Fuzzy Analytical Hierarchy Process Dalam Seleksi Karyawan”, Jurnal Teknik Industri Vol.4 No. 2 Desember 2002: 82-92.

Saaty, T. L., 1990, “The Analytical Hierarchy Process: Planning, Priority Setting, Resource Allocation”, Pittsburgh University Pers.

Saaty, T. L., 2006, "Decision Making with the Analytic Network Process: Economic, Political, Social and Technological Applications with Benefits, Opportunities, Costs and Risks", Springer. New York.

Turner, 1982., "Housing by People, Toward Autonomy in Building Environments", Moris Boyars Publishers Ltd. London.

C.C.M. Siddique., "Properties and Applications (ed.)", Woodhead Publishing Series in Civil and Structural Engineering, pp. 1-30, Woodhead Publishing.

T. Soetens, S. Matthys, 2017, "Shear-Stress Transfer Across A Crack In Steel Fibre- Reinforced Concrete, Cement and Concrete Composites", Belgia.

Wight, J.K. \& MacGregor, J.G., 2012, "Reinforced Concrete Mechanics and Design" 